\section{Monograf Analisis \\ Hubungan Pengetahuan \& Motivasi untuk Melakukan Vaksinasi HPV}

Kanker serviks adalah infeksi Human Papilloma Virus (HPV). Virus ini terutama ditularkan melalui hubungan seksual Diperkirakan $80 \%$ wanita terpapar oleh HPV sepanjang hidupnya. HPV memiliki lebih dari 100 macam tipe, yang dapat menyebabkan kanker serviks sekitar 14 tipe sedangkan tipe-tipe yang lainnya dapat menimbulkan kutil pada daerah genital (genital warts). Tipe yang paling sering menyebabkan kanker serviks adalah HPV tipe 16 dan 18.

Pemberian vaksin HPV pada kenyataannya ada yang mau melakukan dan ada yang tidak mau melakukan, bagi yang mau melakukan, dikarenakan mengetahui dan menyadari betapa pentingnya mencegah penyakit kanker serviks.

Vaksin HPV adalah obat yang berisi protein HPV (cangkang HPV) yang dapat merangsang pembentukan antibody dapat mematiakn kuman/virus penyebab 18 penyakit yang tidakmengandung DNA-HPV

Selain membentengi dari penyakit kanker serviks, yang perlu ditekankan adalah, vaksinasi ini baru efektif apabila diberikan pada perempuan berusia 9 sampai 26 tahun yang belum aktif secara seksual dan bagi yang sudah berhubungan badan sebaiknya dilakukan pemeriksaan pap smear atau tehnik IVA terlebih dahulu untuk mengetahui sudah terinfeksi HPV atau belum karena vaksin berfungsi untuk mencegah bukan untuk mengobati infeksi yang sudah terjadi, dan apabila sudah terinfeksi HPV dapat diamati sampai 2 tahun dan apabila infeksi sudah hilang maka vaksin bisa diberikan

Analisis Hubungan Pengetahuan dan Motivasi Karyawan Untuk melakukan Vaksinasi HPV, dikategorikan baik dan motivasi karyawan tentang vaksinasi HPV dikategorikan positif, jadi ada hubungan antara pengetahuan dengan vaksinasi HPV

\section{Anita Herawati}
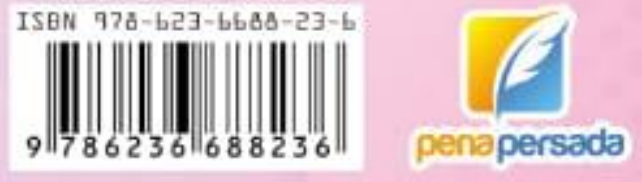

\section{Monograf Analisis Hubungan
Pengetahuan Analisis Hubungan
Pengetahuan \& Motivasi untuk Melakukan Vaksinasi} we 


\section{MONOGRAF}

ANALISIS HUBUNGAN PENGETAHUAN DAN MOTIVASI UNTUK MELAKUKAN VAKSINASI HPV

ANITA HERAWATI

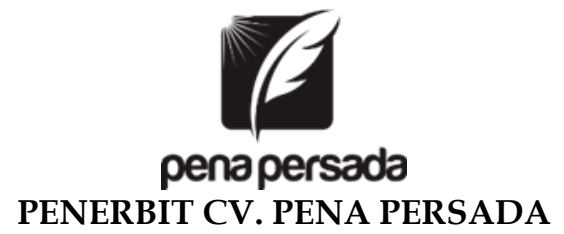




\section{MONOGRAF \\ ANALISIS HUBUNGAN PENGETAHUAN DAN MOTIVASI \\ UNTUK MELAKUKAN VAKSINASI HPV}

Penulis:

Anita Herawati

ISBN : 978-623-6688-23-6

Design Cover :

Retnani Nur Briliant

Layout :

Hasnah Aulia

\section{Penerbit CV. Pena Persada \\ Redaksi :}

Jl. Gerilya No. 292 Purwokerto Selatan, Kab. Banyumas

Jawa Tengah

Email : penerbit.penapersada@gmail.com

Website : penapersada.com Phone : (0281) 7771388

Anggota IKAPI

All right reserved

Cetakan pertama : 2020

Hak cipta dilindungi oleh undang-undang. Dilarang memperbanyak karya tulis ini dalam bentuk apapun tanpa izin penerbit 


\section{KATA PENGANTAR}

Dengan memanjatkan Puji dan Syukur penulis panjatkan Kehadirat Allah SWT atas berkat Rahmat dan Kehendak-Nya jualah Sehingga Penulis dapat menyelesaikan Buku Monograf yang Berjudul "Analisis Hubungan pengetahuan dan motivasi Untuk melakukan vaksinasi HPV “ ini dapat di selesaikan.

Buku Monograf ini diharapkan dapat menjadi referensi tambahan dan khasanah ilmu pengetahuan bagi masyarakat agar dapat menambah wawasan dan pengetahuan tentang kanker servik yang dapat dideteksi secara dini dengan pemeriksaan Iva dan pencegahan dengan Vaksinasi HPV

Penulis menyadari bahwa dalam penyelesaian penulisan monograf ini tidak terlepas dari bantuan berbagai pihak, Semoga Allah SWT memberikan balasan pahala dan amal jariah atas segala ilmu yang telah di berikan. Akhir kata semoga Buku Monograf ini dapat bermanfaat bagi kita semua, Amin

Banjarmasin, Juli 2020

Penulis 


\section{DAFTAR ISI}

KATA PENGANTAR ............................................................... iii

DAFTAR ISI ........................................................................ iv

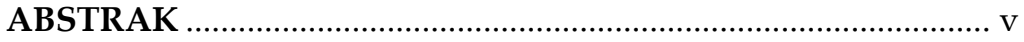

ABSTRACT …..................................................................... vi

BAB I PENDAHULUAN …................................................. 1

A. Latar Belakang ................................................................. 1

B. Rumusan Masalah ................................................................... 2

C. Tujuan Penelitian........................................................................ 2

D. Manfaat Penelitian ......................................................... 3

BAB II TINJAUAN PUSTAKA ................................................ 4

A. Landasan Teori ....................................................................... 4

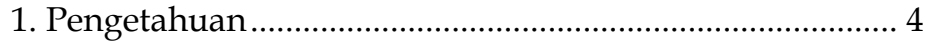

2. Motivasi ................................................................................. 6

3. Kanker Serviks ................................................................ 13

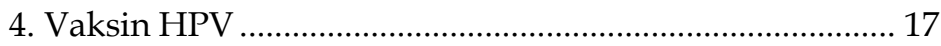

BAB III METODE PENELITIAN ............................................. 20

A. Kerangka Konsep ............................................................ 20

B. Definisi Operasional ................................................................. 20

C. Rancangan Penelitian.............................................................. 21

D. Lokasi dan Tempat Penelitian .............................................. 22

E. Populasi dan sampel ........................................................ 22

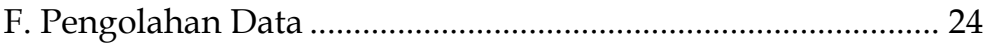

G. Analisa Data........................................................................... 25

BAB IV HASIL DAN PEMBAHASAN ..................................... 28

A. Hasil ................................................................................. 28

B. Pembahasan......................................................................... 33

BAB V KESIMPULAN DAN SARAN ................................... 35

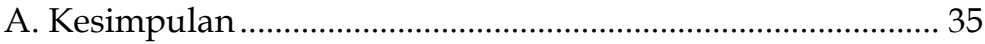

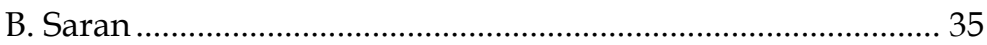

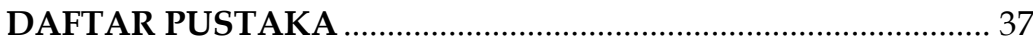




\begin{abstract}
ABSTRAK
Latar Belakang : Depertemen Kesehatan RI memperkirakan bahwa setiap 1 jam seorang wanita Indonesia meninggal akibat kanker serviks dengan tingkat kejadian 100/1000 penduduk / tahun. Penyebab utama (99\%) kanker serviks adalah infeksi Human Papilloma Virus (HPV). Virus ini terutama ditularkan melalui hubungan seksual Diperkirakan $80 \%$ wanita terpapar oleh HPV sepanjang hidupnya. HPV memiliki lebih dari 100 macam tipe, yang dapat menyebabkan kanker serviks sekitar 14 tipe sedangkan tipe-tipe yang lainnya dapat menimbulkan kutil pada daerah genital (genital warts). Tipe yang paling sering menyebabkan kanker serviks adalah HPV tipe 16 dan 18. Pemberian vaksin HPV pada kenyataannya ada yang mau melakukan dan ada yang tidak mau melakukan, bagi yang mau melakukan, dikarenakan mengetahui dan menyadari betapa pentingnya mencegah penyakit kanker serviks.
\end{abstract}

Tujuan: Untuk Menganalisis Hubungan Pengetahuan dan Motivasi karyawan untuk melakukan Vaksinasi HPV.

Metode: penelitian yang digunakan dalam penelitian ini adalah seluruh karyawan wanita di Rumah Sakit Y Banjarmasin. Sampel adalah sebagian dari populasi diambil dengan

Quota Sampling yang berjumlah 66 orang. Pengumpulan data dengan cara menggunakan kuesioner dan wawancara di analisis dengan korelasi Spearman Rank dan dilanjutkan dengan R Pearson.

Hasil Penelitian sebagian karyawan memiliki pengetahuan baik ( $63,64 \%$ ). Sebagian karyawan memiliki motivasi yang positif $(71,4 \%)$. Ada hubungan pengetahuan dan motivasi karyawan untuk melakukan vaksinasi HPV.

Saran Instansi kesehatan hendaknya memberikan penyuluhan kepada karyawan tentang pentingnya vaksinasi HPV.

Kata kunci: Pengetahuan, Karyawan, Motivasi melakukan Vaksinasi HPV. 


\begin{abstract}
Background: The Indonesian Ministry of Health estimates that every 1 hour an Indonesian woman dies from cervical cancer with an incidence rate of 100/1000 residents / year. The main cause $(99 \%)$ of cervical cancer is Human Papilloma Virus (HPV) infection. This virus is mainly transmitted through sexual intercourse It is estimated that $80 \%$ of women are exposed to HPV throughout their lives. HPV has more than 100 types, which can cause cervical cancer about 14 types while other types can cause warts in the genital area (genital warts). The type that most often causes cervical cancer is HPV types 16 and 18. Giving the HPV vaccine is in fact there are those who want to do and some who do not want to do, for those who want to do, because they know and realize how important it is to prevent cervical cancer.
\end{abstract}

Purpose: To Analyze the Relationship of Knowledge and Motivation of employees to carry out HPV Vaccination.

Method: The research used in this study was all female employees at Banjarmasin Hospital Y. Samples are a portion of the population taken with

Sampling quota, amounting to 66 people. Data collection by using questionnaires and interviews were analyzed with Spearman Rank correlation and continued with R Pearson.

Research Results some employees have good knowledge (63.64\%). Some employees have positive motivation (71.4\%). There is a relationship between knowledge and motivation of employees to carry out HPV vaccinations.

Suggestion Health agencies should provide counseling to employees about the importance of HPV vaccination

Keywords: Knowledge, Employees, Motivation for HPV Vaccination. 


\section{BAB I \\ PENDAHULUAN}

\section{A. Latar Belakang}

Depertemen Kesehatan RI memperkirakan bahwa setiap 1 jam seorang wanita Indonesia meninggal akibat kanker serviks dengan tingkat kejadian 100/1000 penduduk / tahun. Penyebab utama (99\%) kanker serviks adalah infeksi Human Papilloma Virus (HPV).

Riwayat infeksi di daerah kelamin dan radang panggul. Infeksi menular seksual (IMS) dapat menjadi peluang meningkatnya resiko terkena kanker serviks. Sosial ekonomi, karsinoma serviks banyak dijumpai pada golongan sosiaekonomi rendah mungkin faktor sosial ekonomi erat kaitannya dengan gizi, imunitas, dan kebersihan perseorangan. Pada golongan sosial ekonomi rendah umumnya kuantitas dan kualitas makanan kurang hal ini mempengaruhi imunitas tubuh. Kumalasari \& Andhyantoro (2012)

Data yang didapatkan dari YKI cabang Kalimantan Selatan di Banjarmasin yang melakukan pap smear sebanyak 365 orang melakukan pemeriksaan pap smear dan 596 orang melakukan IVA, serta 10 orang atau sekitar $1 \%$ menderita kanker servik stadium lanjut, dari beberapa orang yang melakukan pemeriksaan tersebut didapatkan $40 \%$ mendapatkan hasil positif diduga mengalami kelainan pada serviknya yang mengarah pada kanker serviks.

Melalui vaksinasi semakin besar kesempatan disembuhkannya penyakit ini dan semakin besar kemungkinan untuk menekan angka kasus kanker serviks yang mengancam kaum perempuan. Menurut American College of Obstetricians and Gynaecologist (ACOG), vaksinasi $H P V$ wajib diberikan secara rutin pada wanita usia 11-12 tahun dan wajib diberikan pada wanita usia 13 - 26 tahun yang belum mendapatkan vaksinasi 
$H P V$. Namun dapat pula diberikan mulai usia 9 tahun (Suheimi dkk, 2010).

Pemberian vaksin HPV pada kenyataannya ada yang mau melakukan dan ada yang tidak mau melakukan, bagi yang mau melakukan, dikarenakan mengetahui dan menyadari betapa pentingnya mencegah penyakit kanker serviks. Angka kejadian kanker

serviks yang masih cukup tinggi, disebabkan mereka yang terdiagnosa kanker serviks datang sudah dalam keadaan stadium lanjut yang diakibatkan karena kurangnya akses skrining, pengetahuan tentang kanker serviks, sehingga mereka tidak termotivasi untuk mendapatkan vaksin HPV sebagai pencegahan kanker serviks (Suhaimi dkk, 2010).

Data karyawan Rumah Sakit Y berjumlah 299 orang dengan jumlah karyawan perempuan 186 orang dan karyawan laki-laki 113 orang dengan tingkat pendidikan yang berbeda dari tingkat dasar sampai sarjana sehingga hal itu menarik minat peneliti untuk meneliti bagaimana hubungan antara pengetahuan tentang kanker serviks dengan motivasi mereka untuk melakukan tindakan pencegahan melalui pemberian vaksin $\mathrm{HPV}$

\section{B. Rumusan Masalah}

Berdasarkan latar belakang masalah tersebut di atas untuk mengidentifikasi apakah ada hubungan pengetahuan dan motivasi karyawan untuk melakukan vaksinasi HPV

\section{Tujuan Penelitian}

Tujuan Penelitian ini yaitu :

1. Untuk Menganalisis Hubungan Pengetahuan karyawan untuk melakukan vaksinasi HPV

2. Untuk memberikan motivasi agar dapat melakukan vaksinasi HPV

3. Memberian kostribusi untuk pencegahan secara dini terhadap terjadinya kanker serviks 


\section{Manfaat Penelitian}

Berdasarkan tujuan penelitian yang ingin dicapai adalah :

1. Bagi Responden

Diharapkan dengan adanya penelitian ini dapat memberikan masukan pengetahuan serta wawasan tentang kesehatan reproduksi wanita terutama pengetahuan dan motivasi dengan pemberian vaksin HPV. Sehingga dengan adanya pengetahuan yang cukup dapat meningkatkan kesadaran untuk melakukan pencegahan dini terhadap kanker serviks.

2. Bagi Tenaga Kesehatan

Penelitian ini dapat digunakan sebagai bahan masukan untuk memberikan pelayanan dan penyuluhan kepada wanita di wilayah kerja masing-masing guna membantu para wanita yang berhak untuk mendapatkan pelayanan kesehatan yang baik,mudah dan terjangkau

3. Bagi Peneliti

Hasil penelitian ini diharapkan dapat dijadikan sebagai bahan masukan atau informasi bagi petugas kesehatan dalam memberikan penyuluhan tentang pemberian vaksin HPV. 


\section{BAB II TINJAUAN PUSTAKA}

A. Landasan Teori

\section{Pengetahuan}

a. Definisi Pengetahuan

Pengetahuan adalah merupakan hasil "tahu" dan ini terjadi setelah orang melakukan penginderaan terhadap suatu objek tertentu. Penginderaan terjadi melalui panca indra manusia, yakni indera penglihatan, pendengaran, penciuman, rasa dan raba menurut Bachtiar yang dikutip dari Notoatmodjo (2012).

Pengetahuan sangat erat hubungannya dengan pendidikan, dimana diharapkan bahwa dengan pendidikan yang tinggi maka orang tersebut akan semakin luas pula pengetahuannya. Akan tetapi perlu ditekankan, bukan berarti seseorang yang berpendidikan rendah mutlak berpengetahuan rendah pula. Pengetahuan seseorang tentang suatu objek mengandung dua aspek yaitu aspek positif dan aspek negatif. Kedua aspek ini akan menentukan sikap seseorang, semakin banyak aspek positif dan objek yang diketahui, maka akan menimbulkan sikap positif terhadap objek tertentu. Menurut teori WHO (word health organization), salah satu bentuk objek kesehatan dapat dijabarkan oleh pengetahuan yang diperoleh dari pengalaman sendiri (Wawan,2010)

b. Tingkatan Pengetahuan Dalam Domain Kognitif

Pengetahuan seseorang terhadap objek mempunyai intensitas atau tingkat yang berbeda - beda. Secara garis besarnya dibagi 6 tingkat, yakni : (Notoatmodjo, 2014) 
1. Tahu (know)

Tahu diartikan hanya sebagai recall (memanggil) memori yang telah ada sebelumnya setelah mengamati sesuatu.

2. Memahami (Comprehensif)

Memahami suatu objek bukan sekedar tahu terhadap objek tersebut, tidak sekedar dapat menyebutkan, tetapi orang tersebut harus dapat mengintreprestasikan secara benar tentang objek yang diketahui tersebut

3. Aplikasi (Aplication)

Aplikasi diartikan apabila orang yang telah memahami objek yang dimaksud dapat menggunakan atau mengaplikasikan prinsip yang diketahui tersebut pada situasi yang lain.

4. Analisis (Analysis)

Analisis adalah kemampuan seseorang untuk menjabarkan dan atau memisahkan, kemudian mencari hubungan antara komponen-komponen yang terdapat dalam suatu masalah atau objek yang diketahui. Indikasi bahwa pengetahuan seseorang itu sudah sampai pada tingkat analisis adalah apabila orang tersebut telah dapat membedakan, atau memisahkan, mengelompokkan, membuat diagram (bagan) terhadap pengetahuan atas objek tersebut

5. Sintesis (synthesis)

Sintesis menunjuk suatu kemampuan seseorang untuk merangkum atau meletakkan dalam satu hubungan yang logis dari komponen-komponen pengetahuan yang dimiliki. Dengan kata lain sintesis adalah suatu kemampuan untuk menyusun formulasi baru dari formulasi-formulasi yang telah ada.

6. Evaluasi, Evaluasi berkaitan dengan kemampuan seseorang untuk melakukan penilaian terhadap suatu objek tertentu. 


\section{Motivasi}

\section{a. Pengertian Motivasi}

Motivasi adalah dorongan yang telah aktif sehingga terjadi perubahan energi dalam diri manusia yang menggerakkannya untuk mencapai tujuannya (Wayan Candra,2015)

Hasibuan (1995) dalam Notoatmodjo (2014) merumuskan definisi motivasi adalah suatu perangsang keinginan dan daya penggerak kemauan yang membuat seseorang bertindak atau berprilaku sehingga mampu mencapai tujuan yang ingin dicapai.

Motivasi adalah daya pendorong yang mengakibatkan seseorang mau dan rela untuk mengerahkan kemampuan dalam bentuk keahlian atau keterampilan tenaga dan waktunya untuk menyelenggarakan berbagai kegiatan yang menjadi tanggung jawabnya dan menuaikan kewajibannya dalam rangka pencapaian tujuan dan berbagai sasaran yang telah ditentukan sebelumnya (Siagian, 2008).

Menurut kamus besar bahasa Indonesia, motivasi adalah dorongan yang timbul pada diri seseorang secara sadar untuk melakukan suatu tindakan dengan tujuan tertentu. Secara umum, motivasi artinya mendorong untuk berbuat atau beraksi. Menurut Nancy Stevenson, motivasi adalah semua hal verbal, fisik atau psikologis yang membuat seseorang melakukan sesuatu sebagai respons. Menurut Sarwono S. W, motivasi menunjuk pada proses gerakan, termasuk situasi yang mendorong yang timbul dalam diri individu, tingkah laku yang ditimbulkan oleh situasi tersebut dan tujuan atau akhir daripada gerakan atau perbuatan (Hamzah, 2009).

Menurut pendapat lain, motivasi itu mempunyai arti dorongan berasal dari bahasa latin Movere yang berarti mendorong seseorang untuk berperilaku beraktifitas untuk mencapai tujuan. 
Teori diatas memberikan cermin bahwa motivasi itu bersifat alami dan kebutuhan menurut Maslow. Teori Maslow tentang kebutuhan manusia ini akan sangat mempengaruhi dorongan atau motivasi seseorang justru dapat dikatakan bahwa urutan lajunya kebutuhan manusia sama dengan berlanjutnya kedalam jenjang motivasi seseorang. Dalam hal ini motivasi sama dengan kebutuhan (Sobur, 2009).

\section{b. Teori Motivasi}

1) Teori Hedonisme

Yaitu motivasi yang berhubungan dengan senang atau gembira, dimana aliran ini memandang bahwa tujuan hidup yang utama pada manusia adalah mencari kesenangan yang bersifat duniawi. Anggapan pada aliran ini bahwa semua orang cenderung menghindari hal-hal yang sulit.

2) Teori Naluri

yaitu motivasi yang ada di dalam diri manusia, maupun kemauan baik atau buruk

3) Teori Kebudayaan

Yaitu motivasi yang akan menimbulkan perilaku berbudaya dimana tindakan atau perilaku manusia tidak berdasarkan naluri. Tetapi berdasarkan pola-pola tingkah laku yang dipelajari dari budaya tempat orang itu hidup.

4) Teori Motivasi berdasarkan kebutuhan (Abraham Maslaw)

Merupakan teori motivasi yang paling terkenal. Maslow berpendapat bahwa kebutuhan manusia sebagai pendorong (motivator) membentuk suatu hirarki atau suatu peringkat. Maslow menggolongkan kebutuhan dalam 5 tingkat ( Hamzah, 2009) :

a) Kebutuhan- kebutuhan yang bersifat fisiologis

Kebutuhan yang dipuaskan untuk dapat tetap hidup misalnya makanan, perumahan, pakaian, udara untuk bernafas, dan sebagainya. 
b) Kebutuhan akan rasa aman

Ketika kebutuhan fisiologis seseorang telah dipuaskan, perhatian dapat diarahkan kepada kebutuhan akan keselamatan. Keselamatan itu, termasuk merasa aman dari setiap ancaman fisik atau kehilangan, serta merasa terjamin.

c) Kebutuhan cinta dan memiliki- dimiliki

Ketika seseorang telah memuaskan kebutuhan fisiologis dan rasa aman, kepentingan berikutnya adalah hubungan antarmanusia. Cinta kasih dan kasih sayang yang diperlukan. dan mungkin melalui hubungan antar pribadi yang mendalam tetapi juga dicerminkan dalam kebutuhan untuk menjadi bagian berbagai kelompok sosial.

d) Kebutuhan penghargaan.

Percaya diri dan harga diri maupun kebutuhan akan pengakuan orang lain. Dalam kaitannya dengan pekerjaan, hal ini berarti memiliki pekerjaan yang dapat diakui sebagai bermanfaat, menyediakan sesuatu yang dapat dicapai, serta pengakuan umum dan kehormatan dari luar.

e) Kebutuhan aktualisasi diri

Ketika semua kebutuhan lain sudah dipuaskan, seseorang ingin mencapai secara penuh potensinya.

Motivasi itu merupakan motor prilaku seseorang/ individu. Semakin kuat motivasi seseorang, maka semakin cepat dalam memperoleh tujuan dan kepuasan.

5) Teori ERG (Existence, Relatedness, Growth)

Umumnya konsep ERG ini merupakan penghaluan dari sistem kebutuhan Maslow, namun berbeda dalam dua aspek. Dalam teori ini Alderfer (1972) mengemukakan 3 kategori kebutuhan diantaranya eksistensi, keterkaitan dan pertumbuhan. 
Dalam kasus ini, suatu kebutuhan yang sudah terpenuhi boleh jadi terus berlangsung menjadi motivator. Sebaliknya kebutuhan akan keterkaitan dan pertumbuhan boleh jadi meningkat ketika terpenuhi (Sobur,2009).

6) Teori Motivasi Dua Faktor

Frederick Herzberg mengemukakan teorinya bahwa motivasi mengandung 2 faktor antara lain faktor kepuasan dan ketidakpuasan. Disini Herzberg menekankan pada kepuasan kerja bahwa para pegawai menginginkan dan mngharapkan gaji yang memadai, jaminan pekerjaan, serta kebutuhan yang layak. Menurutnya, saat kebutuhan dasar ini tidak terpenuhi, para pegawai akan merasa tidak puas dan tidak dapat dimotivasi karena perhatian mereka tertuju pada pemenuhan kebutuhan dasar. Penyediaan kebutuhan ini dapat menghasilkan kepuasan. Tetapi tidak meningkatkan produksi secara langsung (Sobur,2009).

7) Teori Desakan Kebutuhan Murray

Menurut Murray orang dapat dikelompokkan menurut kekuatan berbagai kebutuhan tersebut. Setiap orang dianggap memiliki kebutuhan yang berbeda (kadang- kadang bertentangan) yang mempengaruhi perilaku. Dengan kata lain, kebutuhan dipandang sebagai kekuatan motivasi utama bagi orang dari sisi arah dan intensitas (Sobur,2009).

8) Teori David McClelland

Menurutnya orang yang mempunyai kebutuhan untuk keberhasilan yaitu orang yang mempunyai keinginan kuat untuk mencapai sesuatu. Dalam psikis manusia, ada daya yang mampu mendorongnya ke arah suatu kegiatan yang hebat sehingga dengan daya tersebut, ia dapat mencapai kemajuan yang teramat cepat. Daya tersebut 
dinamakan virus mental karena apabila terjangkit di dalam jiwa manusia, daya tersebut akan berkembang biak dengan cepat, dengan kata lain daya tersebut akan meluas dan menimbulkan dampak dalam kehidupan (Hamzah, 2009).

9) Teori Harapan Vroom

Mengembangkan sebuah teori motivasi berdasarkan jenis- jenis pilihan yang dibuat untuk mencapai suatu tujuan. Teori harapan ini memilki 3 asumsi pokok antara lain (Hamzah, 2009)

a) Setiap individu percaya bahwa ia berperilaku dengan cara tertentu, ia akan memperoleh hal tertentu. Ini disebut harapan hasil

b) Setiap hasil akan mempunyai daya tarik bagi orang tertentu. Ini disebut valensi.

c) Setiap hasil berkaitan dengan suatu persepsi mengenai seberapa sulit mencapai hasil tersebut. Hal ini disebut dengan hasil harapan.

\section{c. Bentuk- Bentuk Motivasi}

1) Motivasi instrinsik atau motivasi yang datangnya dari dalam diri individu itu sendiri

Contoh : A ingin segera lulus D3 Keperawatan, maka muncul dorongan dari dalam dirinya untuk belajar $2 x$ lebih giat daripada waktu masih di SMA.

2) Motivasi ekstrinsik yaitu motivasi yang datangnya dari luar individu

Contoh : karena melihat kedua orang tuanya banting tulang mencari uang untuk mebiayai sekolahnya maka muncul motivasi untuk lebih giat belajar dan lebih cepat selesai sekolah

3) Motivasi Terdesak yaitu motivasi yang muncul dalam kondisi terjepit dan munculnya serentak serta menghentak dan cepat sekali munculnya pada perilaku aktifitas seseorang 
Contoh : Dalam kondisi terdesak $\mathrm{N}$ harus menyelamatkan diri maka ia mampu melompati pagar setinggi 1m lebih dengan baik. Setelah terjadinya aktifitas melompat maka dirasakan sebenar- benarnya, tak mungkin $\mathrm{N}$ dapat melompati pagar setinggi itu. Padahal sebelumnya $\mathrm{N}$ tak pernah melompat setinggi itu.

4) Motivasi yang berhubungan dengan idiologi politik, ekonomi, sosial, dan budaya dan Hankam yang sering menonjol adalah motivasi sosial karena individu itu memang makhluk sosial.

Contoh : Motivasinya muncul untuk bergabung dengan kelompok sukarelawan yang ada, dengan adanya kerusuhan yang menimbulkan korban jiwa dst, ingin membantu meringankan beban.

\section{d. Faktor- Faktor Yang Berpengaruh Pada Motivasi}

1) Faktor yang berpengaruh pada motivasi

2) Faktor fisik dan proses mental, keadaan tubuh dan emosi

3) Faktor hereditas, lingkungan dan kematangan atau usia

4) Faktor instrinsik seseorang, seperti sikap, pengetahuan dan pendidikan.

5) Fasilitas ( sarana dan prasarana), adanya fasilitas kesehatan seperti Rumah Sakit, Puskesmas, Dokter dan Bidan

6) Situasi dan kondisi yang mempengaruhi misal lingkungan sekitar

7) Program dan aktifitas, kegiatan yang dilakukan sehari - hari

8) Audio Visual Aid ( Media), media televisi dan radio

e. Cara meningkatkan motivasi

1) Dengan teknik verbal (berbicara untuk meningkatkan semangat, pendekatan pribadi, diskusi dan sebagainya) 
2) Teknik tingkah laku (meniru, mencoba, menerapkan)

3) Teknik intensif dengan cara mengambil kaidah yang ada

4) Supervisi (kepercayaan akan sesuatu secara logis, namun membawa keberuntungan)

5) Citra/ image yaitu dengan imajinasi atau daya khayal yang tinggi maka individu termotivasi.

\section{f. Pengukuran Motivasi}

Motivasi tidak dapat diobservasi secara langsung namun harus diukur (Notoatmodjo, 2010). Ada beberapa macam cara untuk mengukur motivasi diantaranya sebagai berikut:

1) Tes Proyektif

Tes proyeksi adalah tes yang dilakukan dengan pengungkapan aspek psikologis manusia dengan menggunakan alat proyeksi. Salah satu teknik proyektif yang sering digunakan adalah Thematic Apperception Test (TAT). Dalam tes ini, klien diberikan gambar dank lien diminta untuk membuat cerita tentang gambar tersebut. Dalam teori McClelland dikatakan bahwa manusia memiliki tiga kebutuhan, yaitu kebutuhan untuk berprestasi, kebutuhan untuk berafiliasi dan kebutuhan untuk berkuasa. Melalui isi cerita dari gambar yang sudah klien buat, kita dapat menelaah motivasi yang mendasari diri klien berdasarkan konsep kebutuhan dari McClelland tersebut.

2) Kuisioner

Salah satu cara untuk mengukur motivasi melalui kuisioner adalah dengan meminta klien untuk mengisi kuisioner yang berisi pertanyaanpertanyaan yang dapat memancing motivasi klien.

Pengukuran motivasi dapat mengunakan skala Guttman. Skala ini merupakan skala yang bersifat tegas dan konsisten dengan memberikan jawaban yang tegas ya dan tidak. Apabila responden memilih 
jawaban "ya" nilainya satu dan "tidak" nilainya nol. Kemudian skor dari setiap pernyataan dijumlahkan, dimana skor inilah yang digunakan sebagai indikator dari gejala yang diukur (Hidayat, 2009).

3) Observasi Perilaku

Cara lain untuk mengukur motivasi adalah dengan membuat situasi sehingga klien dapat memunculkan perilaku yang mencerminkan motivasinya. Misalnya, dalam mengobservasi suatu perilaku apakah klien menggunakan umpan balik yang diberikan, mengambil keputusan yang beresiko dan mementingkan kualitas daripada kuantitas.

\section{Kanker Serviks}

a. Pengertian Kanker Serviks

Leher rahim atau servik adalah bagian dari system reproduksi wanita. Servik adalah bagian bawah yang sempit dari rahim atau kandungan. Rahim adalah suatu organ berongga yang berbentuk buah pir pada perut bagian bawah. Mulut rahim atau portio yang menghubungkan rahim ke vagina. Vagina menjurus pada bagian luar tubuh (Setiati,2009).

Kanker servik atau sering dikenal dengan kanker mulit rahim adalah kanker yang terjadi pada servik uterus, suatu daerah pada organ reproduksi wanita yang merupakan pintu masuk kearah rahim yang terletak antara rahim atau uterus dengan liang senggama atau vagina (Nurcahyo,2010).

Menurut dr. Yohanes Riono (1999) kanker servik atau kanker leher rahim dalah kanker yang terjadi pada servik uterus, suatu daerah pada organ reproduksi wanita yang merupakan pintu masuk kearah rahim yang terletak antara uterus dengan vagina. Kanker ini biasanya terjadi pada wanita yang telah berumur.

Kanker leher rahim terjadi jika sel-sel yang ada di daerah tersebut membelah secara tak terkendali dan 